\title{
Representasi Ideologi Islam dalam Cerita Pendek: Analisis Semiotika
}

\author{
Euis Evi Puspitasari ${ }^{1}$, Ahmad Rifai \\ evipuspita2017@gmail.com,mangfai.rifai@gmail.com
}

\begin{abstract}
Abstrak
Penelitian ini menganalisis cerpen berjudul Jaring-jaring Merah sebagai wacana yang dikonstruksikan oleh penulis ceritanya, Helvy Tiana Rosa. Tujuan penelitian ini adalah untuk mengetahui tandatanda yang digunakan Helvy Tiana Rosa dalam mewakili pesan ideologi Islam pada cerpennya. Peneliti menggunakan metode interpretif dengan pendekatan kualitatif dan alat analisis semiotika dari Roland Barthes. Hasil penelitian menúnjukkan bahwa pada teks ditemukan beberapa tanda yang digunakan untuk mewakili ideologi Islam. Ideologi Islam yang mendominasi cerpen ini merepresentasikan tentang keadilan, akhlak perempuan muslim, dan persaudaraan umat Islam. Selain itu, terdapat perspektif fundamentalisme -untuk membedakannya dengan liberalisme- yang dilatarbelakangi oleh dua peristiwa sosial penting, yaitu runtuhnya pemerintahan Orde Baru dan pencabutan status Aceh sebagai Daerah Operasi Militer (DOM). Kedua peristiwa tersebut mendorong Helvy Tiana Rosa selaku pengarang, memunculkan wacana tandingan terhadap hegemoni wacana pada masa itu. Sehingga, pesan yang ditonjolkan memiliki kecenderungan dan pola yang berpihak kepada kaum tertindas.
\end{abstract}

Kata kunci: Akblak, Ideologi, Islam, Keadilan, Semiotika

\begin{abstract}
This study analyzed the short story titled Red Nets as a discourse constructed by the author of the story, Helvy Tiana Rosa. The purpose of this study is to determine the signs used Helvy Tiana Rosa in representing the message of Islamic ideology in the short story. Researchers use interpretive methods with qualitative approach and semiotics analysis tools from Roland Barthes. The results showed that the text found several signs used to represent the ideology of Islam. Islamic ideology that dominates this short story represents about justice, morality of Muslim women, and the brotherhood of Muslims. In addition, there is a fundamentalist perspective - to distinguish it from liberalism - underpinned by two important social events, namely the collapse of the New Order government and the abrogation of the status of Aceh as a Military Operation Area (DOM). Both events encouraged Helvy Tiana Rosa as the author, bringing counter discourse to the hegemony of discourse at that time. Thus, the message highlighted has a tendency and pattern that stands for the oppressed.
\end{abstract}

Keyword: Akblak, Ideology, Islam, Justice, Semiotics

\section{Pendahuluan}

Teks fiksional yang lahir di era kapitalisme mendorong para penulisnya untuk memproduksi karya sesuai tuntutan pasar tanpa melihat tujuan yang hendak dicapai.

\footnotetext{
${ }^{1}$ Korespondesi: Euis Evi Puspitasari. Prodi Ilmu Komunikasi Universitas Muhammadiyah Bandung, Jl. Palasari no 9A Kota Bandung 40262, telp. 022-7302188-7333633, email: info@umbandung.ac.id
} 
Industrialisasi karya fiksi memang tidak bisa dihindari. Hal ini pula yang mendorong terciptanya karya-karya instan, karya-karya popular, yang di satu pihak berpretensi menyampaikan pesan, di pihak lain ditempatkan sebagai komoditas. Jika orientasi penulis karya fiksi hanya berfokus untuk tujuan komersial tanpa mengindahkan norma moral dan adat ketimuran, apalagi kaidah agama, remaja kita akan kehilangan jati diri sebagai bangsa yang bermartabat. Oleh karena itu, seorang penulis fiksi diharapkan dapat menjadi pendidik yang juga memikirkan dampak karyanya bagi para pembaca. Dalam karya fiksi, diharapkan tidak hanya mengekspresikan hal-hal yang bersifat kesenangan tetapi diharapkan ada endapan pengalaman yang mewakili nilai- nilai estetik dan profetik untuk menyadarkan kita pada kehadiran Yang Maha Kuasa.

Sastrawan atau penulis fiksi yang rajin menghadirkan Yang Maha Kuasa dalam karyanya dapat kita temui pada Forum Lingkar Pena (FLP), yaitu sebuah organisasi yang mewadahi para penulis teks fiksional mulai dari anak-anak, remaja, hingga dewasa. Forum Lingkar Pena adalah komunitas penulis dan calon penulis yang didirikan 22 Februari 1997. Dalam dua puluh tahun perkembangannya, FLP menjadi wadah ribuan orang untuk mengasah diri sebagai pengarang atau penulis, yang telah menerbitkan lebih dari 600 buku, bekerjasama dengan tak kurang dari 30 penerbit. Data yang berhasil diperoleh dari Yeni Mulati atau dikenal dengan nama pena Afifah Afra, Ketua Umum Badan Pengurus Pusat FLP, penulis yang bergabung dengan organisasi ini berjumlah 1581 orang dan tersebar di 29 wilayah dan 63 cabang daerah kabupaten/kota, provinsi dan di mancanegara. Anggota FLP yang pulang ke tanah air pun terus bergiat menyelesaikan karya seperti Awy Qolawwun yang merupakan alumni FLP Arab Saudi, Adly el Fadly yang merupakan alumni FLP Yaman, Irja Nashrullah yang masih aktif di FLP Mesir.

Munculnya wadah semacam Forum Lingkar Pena (FLP) dan Komunitas Azan sebagai fenomena munculnya sastra Islami, sastra dzikir, sastra santri atau sastra pesantren perlu disambut baik sebagai proses kesadaran ummat akan pentingnya makna kesempurnaan sebuah karya sastra yang di dalamnya terkandung estetika dan kebenaran nurani. Kehadiran fiksi Islami ini diharapkan bisa menjadi sebuah budaya tandingan terhadap fiksi yang beredar dewasa ini di dunia penulisan fiksi, sebagaimana yang dikatakan oleh 
Mulyana dalam pengantar sebuah antologi cerpennya yang berjudul Bidadari Kerudung Biru. Menurut Mulyana, kita sebagai kaum muslim perlu membangun sebuah 'co-culture' tersendiri untuk mengimbangi fiksi yang kita nilai kurang bermanfaat bagi jati diri muslim (Mulyana, 2005 : xii).

Helvy Tiana Rosa yang telah mendirikan komunitas FLP dianggap sebagai pelopor genre baru sastra kontemporer Indonesia. Adapun misi yang sangat kental ia bawa adalah misi keagamaan. Menurut Helvy, sastra harus memberikan 'ghirab' keilahian. Sastra wajib berpihak pada kebenaran dan keadilan. Sastra yang diusung harus diniati dengan muatan dakwah. Kegiatan menghasilkan suatu karya merupakan refleksi 'amar makruf nahi munkar? Kekuatan keyakinan pada Allah adalah segala-galanya, di mana segi syariat dan hakikat harus terbawa. Sastra Islam adalah sastra karena Allah untuk umat manusia (Rosa, 2003:4).

Muatan dakwah yang dimaksud Helvy (2003) berkorelasi dengan tujuan komunikasi yaitu untuk mengubah sikap, perilaku, opini, pendapat, pandangan, dan pada akhirnya mengubah masyarakat. Bahkan cara berdakwah melalui cerpen ini, tampaknya sama efektifnya seperti melalui forum ceramah di majlis taklim, siaran radio, dan di layar televisi ataupun melalui media lain seperti film, sinetron, musik, nasyid, dan komik.

Oleh karena itu, hal ini menarik perhatian peneliti untuk mengetahui dan mengkaji lebih dalam isi pesan dari fiksi Islami, khususnya cerpen Helvy Tiara Rosa. Pemilihan cerpen Helvy Tiara Rosa sebagai objek penelitian didasarkan pada pertama kemahirannya dalam mengomunikasikan pengetahuan dan pengalaman religiusnya dalam teks fiksional atau cerpen. Kedua, isi pesan cerpennya tidak hanya memenuhi kriteria Horatius dulce et utile (nikmat dan bermanfaat), tetapi juga dipenuhi muatan dakwah Islam. Ketiga teks fiksionalnya ini penting ditelaah untuk menemukan ideologi yang tersembunyi di dalamnya.

Bertolak dari latar belakang tersebut, penelitian ini dibatasi secara substansial dan metodologis. Secara substansial, penelitian ini merupakan penelitian terhadap teks cerpen sebagai wacana yang dikonstruksikan oleh penulisnya, Helvy Tiana Rosa, dan secara metodologis penelitian ini memfokuskan diri pada teks fiksional yang berkaitan 
dengan ideologi Islam. Dengan demikian, penulis tertarik untuk menganalisis tanda-tanda yang digunakan Helvy Tiana Rosa dalam cerpennya untuk mengomunikasikan ideologi Islam.

\section{Tinjauan Pustaka}

Sebagai sebuah kelaziman, produk apapun yang lahir di era kapitalisme ditempatkan sebagai komoditas. Industrialisasi karya fiksi memang tidak bisa dihindari. Masalahnya, jika orientasi penulis teks fiksional tersebut hanya untuk tujuan komersial belaka tanpa mengindahkan norma moral dan adat ketimuran, apalagi kaidah agama, remaja kita akan kehilangan jati diri sebagai bangsa yang bermartabat. Oleh karena itu seorang penulis teks fiksional diharapkan dapat menjadi pendidik yang selalu memikirkan dan memberi pencerahan bagi pembacanya.

Diantara maraknya teks fiksional remaja yang bertema romantisme anak gaul tersebut, terselip teks-teks fiksional yang konsisten mengusung tema dakwah Islam. Pelopor teks fiksional remaja bertema dakwah Islam ini adalah seorang wanita, Helvy Tiana Rosa, yang karyanya banyak berbentuk cerpen. Baik novel maupun cerpen, merupakan teks fiksional yang diakui keberadaanya di samping puisi dan drama. Bagi Helvy, berdakwah melalui cerpen sudah menjadi bagian dari kewajiban dirinya sebagai seorang muslimah sejati. Cerpen menjadi media mengomunikasikan syiar Islam, menyerukan kasih sayang, keadilan, kebenaran, dan hak azasi manusia. Dengan kata lain menyampaikan firman Tuhan secara tersurat maupun tersirat.

\section{Komunikasi Puitik}

Komunkasi linear yang terbangun dalam sebuah teks fiksional disebut komunikasi puitik. Penyusunan spesifikasi di atas didasarkan pada sistem komunikasi verbal yang menurut Jakobson (dalam Sobur, 2012:142) mengandung komponen (i) pembicara (addresser), (ii) konteks pertuturan, (iii) pesan, (iv) kontak (v) kode sebagai wahana encoding dan decoding, dan (vi) pendengar (addressee). Dalam komunikasi tersebut, pembicara dan pendengar berada dalam hubungan langsung. Dikaitkan dengan komponen-komponen komunikasi tersebut, bahasa sebagai wahana memiliki fungsi yang 
berbeda-beda. Setelah dihubungkan dengan karakteristik komunikasi sastra, fungsi bahasa ditentukan meliputi fungsi (i) emotif, (ii) referensial, (iii) puitik, (iv) fatis, (v) metalingual atau metabahasa, dan (vi) konatif. Laswell menghendaki agar komunikasi dijadikan objek studi ilmiah, bahkan setiap unsur diteliti secara khusus. Studi mengenai komunikator dinamakan control analysis; penelitian mengenai pers, radio, televisi, film, dan media lainnya disebut media analysis; penelitian mengenai pesan dinamai content analysis; studi tentang komunikan disebut audience analysis; penelitian mengenai efek atau dampak yang ditimbulkan komunikasi disebut effect analysis.

Berkenaan dengan penelitian ini, cerpen berjudul Jaring-jaring Merah merupakan media yang berisi pesan verbal tertulis bermuatan dakwah Islam yang disampaikan oleh pengarang sebagai komunikatornya yaitu Helvy Tiana Rosa tidak hanya sebagai ekspresi dari perasaan dan pikiran pengarang tetapi sekaligus juga sebagai refleksi dari keyakinannya beramar makruf nahi munkar; mengajak kepada kebenaran dan menolak kemungkaran. Karena penelitian ini menganalisis pesan, penelitiannya disebut analisis isi atau content analysis.

\section{Teks sebagai Pesan Komunikasi}

Selain definisi yang telah disampaikan di muka, pesan dalam kajian komunikasi dapat diartikan sebagai lambang-lambang bermakna yang dikirim dari salah satu peserta komunikasi kepada peserta lainnya., dengan tujuan tertentu (with purpose). Dalam proses komunikasi, apa pun sifat dan bentuk komunikasinya, pesan merupakan elemen penting yang membangun proses komunikasi tersebut (Zoest dalam Sobur, 2012:128). Cerpen dibangun oleh tanda semata-mata. Tanda-tanda tersebut bekerja sama membangun sebuah makna tertentu dan mencapai efek pesan yang diharapkan. Jika proses komunikasi berjalan dengan baik (buku terjual dan pembeli membacanya), pengirim tanda yaitu pengarang, mencapai khalayak pembaca sebagai penerima tanda yang di dalam pikirannya terjadi suatu proses penafsiran. Proses penafsiran ini dapat terjadi karena tanda yang bersangkutan merujuk pada suatu kenyataan (denotatum), sejalan dengan pendapat Budiman (dalam Sobur, 2009: 53), bahwa

teks juga dapat diartikan sebagai seperangkat tanda yang ditransmisikan dari seorang pengirim kepada penerima melalui medium tertentu dan dengan kode-kode tertentu. 
Pihak penerima _ yang menerima tanda-tanda tersebut sebagai teks_ segera mencoba menafsirkannya berdasarkan kode-kode yang tepat dan telah tersedia.

Cerpen dapat dikategorikan sebagai karya tulis sastra. Menurut Mulyana (Mulyana, 2005:xi),

setiap karya tulis, apakah itu termasuk sastra atau bukan, sebenarnya tidak lahir dan muncul dalam ruang vakum sosial atau vakum nilai. Setiap orang pada dasarnya bebas mengekspresikan pengalaman hidupnya dan nilai-nilai yang dianutnya lewat karya tulis, meskipun para penulis tersebut harus mempertimbangkan nilai-nilai yang dianut oleh para pembacanya).

\section{Cerpen dan Fungsi Komunikasi Ekspresif}

William I Gorden (Mulyana, 2007:5) mengemukakan bahwa ada empat fungsi komunikasi yang keempat fungsi tersebut tidak saling meniadakan (mutually exclusive), yaitu komunikasi sosial, komunikasi ekspresif, komunikasi ritual, dan komunikasi instrumental. Penulisan sebuah cerita pendek (disingkat cerpen; Inggris: short story) sangat relevan dengan fungsi komunikasi ekspresif di mana fungsi komunikasi ekspresif tersebut tidak otomatis bertujuan mempengaruhi orang lain, namun dapat dilakukan sejauh komunikasi tersebut menjadi instrumen untuk menyampaikan perasaan-perasaan (emosi) kita.

Sebagai ekspresi dan hasil kreativitas imajinatif para penulisnya, cerpen dapat menjadi sarana untuk menyalurkan emosi dan mengkomunikasikan visi dan misi penulisnya. Untaian kata yang dituliskan penulis sebuah cerpen, mengungkapkan ekspresi tertentu yang mewakili ide, pola pikir, dan imajinasinya. Cerpen karya Helvy Tiana Rosa tidak hanya merupakan suatu perjalanan atau penjelajahan, selebihnya merupakan reaksi mental seorang muslimah yang merindukan kebenaran dan keadilan. Sebuah kepedulian terhadap pendidikan spiritual para remaja yang biasanya hanya dijejali oleh cerita tanpa misi dan visi yang jelas, atau sekadar penghibur di waktu luang.

\section{Metode}

Penulis menggunakan metode penelitian interpretif. Metode dan analisisnya bersifat kualitatif. Jenis penelitian ini memberikan peluang yang besar bagi dibuatnya 
interpretasi-interpretasi alternatif (Littlejohn, 2009:16). Konsekuensi logis dari metode interpretif yang menaruh perhatian pada interpretasi makna, khususnya pada teks adalah tidak bisa dilepaskannya unsur subjektifitas dari sang pemberi makna, sebagaimana dikatakan oleh Eriyanto (2011 : 59) bahwa pada proses pemaknaan itu, keberpihakan peneliti dan posisi peneliti atas suatu masalah sangat menentukan bagaimana data/teks ditafsirkan.

Teknik analisis data dilakukan dengan langkah sebagai berikut; data ditulis dalam bentuk uraian terperinci, kemudian direduksi, dirangkum, dan dipilih hal-hal pokok, serta difokuskan pada hal-hal yang penting saja atau signifikan dengan tujuan penelitian. Dari data yang telah dipilih, digali makna yang terkandung di dalamnya, kemudian dicoba untuk diambil simpulannya

Penelitian teks yang dianalisis dengan menggunakan semiotika Roland Barthes ini lebih menitikberatkan pada fenomena sosial yang mengandung konotasi dan mitologi. Dalam kerangka Barthes, konotasi identik dengan operasi ideologi, yang disebutnya sebagai mitos dan berfungsi untuk mengungkapkan dan memberikan pembenaran bagi nilai-nilai dominan yang berlaku dalam suatu periode tertentu (Budiman dalam Sobur, 2003:71). Mitos akan menyingkap dan memurnikan apa yang tersembunyi dalam suatu teks. Menurut Bakhtin (dalam Widiningtyas, 2002:54) segala sesuatu yang bersifat ideologi merupakan tanda. Tanpa tanda, maka tidak ada ideologi. Penggunaan tanda-tanda akan memberi hidup pada ideologi.

Roland Barthes juga menggunakan konsep dalam teori Saussure berupa hubungan sintagmatik dan paradigmatik yang mengelompokkan kedua konsep itu ke dalam aspek sintaksis dan semantik. Sintagmatik adalah hubungan yang bersifat linear. Hubungan tersebut adalah hubungan antara penanda dengan petanda, hubungan antara unsur-unsur yang hadir secara bersama. Karena aspek formal karya itu yang berupa deretan kata, kalimat, alinea, dan seterusnya dapat dilihat kehadirannya dalam teks itu, hubungan itu juga disebut, hubungan in praesentia. Paradigmatik adalah hubungan bersifat asosiatif. Hubungan aspek formal dengan aspek makna, hubungan antara unsur yang hadir dengan 
yang tidak hadir, yaitu makna yang hanya dapat diasosiasikan oleh karena itu disebut juga hubungan in absentia (Nurgiantoro,2000:46).

\section{Hasil dan pembahasan}

\section{Analisis Paradigmatik}

Ketika membaca sebuah cerpen, kita tidak hanya membaca rangkaian cerita yang ditulis pengarang, tetapi pada saat bersamaan akan muncul sebuah penafsiran dan pemaknaan terhadap apa yang kita baca. Demikian pula pada saat kita membaca cerpen berjudul Jaring-jaring Merah ini. Dari bagian awal hingga akhir kisah, pengarang banyak menggunakan metafora yaitu pemakaian kata atau kelompok kata bukan dengan arti yang sebenarnya, melainkan sebagai lukisan yang berdasarkan persamaan atau perbandingan. Kata atau kelompok kata tersebut sekaligus menjadi penanda denotative yang memunculkan petanda konotatif.

Teks berjudul Jaring-jaring Merah ini dianalisis menggunakan semiotika. Pertama menggunakan analisis paradigmatik pada bagian yang signifikan, kemudian baru dilakukan analisis sintagmatik pada semua bagian tersebut. Analisis paradigmatik adalah pengujian suatu rangkaian dari mana suatu pilihan dibuat dan hanya satu unit dari set tersebut yang hanya dapat dipilih. Analisis paradigmatik akan dilakukan pada bagian yang signifikan, dalam penelitian ini tentu saja berkenaan dengan pesan Islam yang direpresentasikan dalam bentuk cerpen. Berikut ini ideologi yang diusung dalam cerpen ini.

\section{Ideologi tentang Keadilan.}

Cerpen ini sarat dengan penggambaran kezaliman yang terjadi di Aceh saat diberlakukan Operasi Jaring Merah. Dikotomi antara penindas dan tertindas begitu mencuat, mendominasi alur cerita dalam cerpen ini. Penanda-penandanya dapat dilihat dalam kalimat di bawah ini,

Oi, tahukah anjing-anjing buduk itu, aku melihat tiga sampai tujuh mayat sehari mengambang di sungai dekat rumahku! Aku juga pernah lihat Yunus Burong ditebas lehernya dan kepalanya dipertontonkan pada penduduk desa. Aku melihat orang-orang ditembak di atas sebuah truk kuning. Darah mereka muncrat ke mana-mana. Aku melihat tetanggaku Rohani 
ditelanjangi, diperkosa beramai-ramai, sebelum rumah dan suaminya dibakar. Aku melihat saat Geuchik. Harun diikat pada sebuah pohon dan ditembak berulangkali. Aku melihat semua itu! Ya, semuanya. Juga saat mereka membantai... keluargaku, tanpa alasan. (hal 2)

Paragraf di atas merupakan penanda-penanda yang memiliki relasi dan mendukung satu petanda, yaitu kazaliman, kekejian, dan penindasan. Di sini pengarang mencoba menanamkan ideologi dengan membawa pembaca pada keadaan emosional, menggiring pembaca pada posisi prihatin terhadap keadaan yang menimpa tokoh utama yang mengalami berbagai perlakuan represif dari aparat militer. Tujuan pengarang selain untuk menyulut perasaan iba dari pembaca juga mengajak pembaca untuk mengutuki perbuatan kejam dan ketidakadilan yang menimpa rakyat Aceh saat diberlakukan. Operasi Jaring Merah (OJM). Ideologi yang ditanamkan pengarang adalah keadilan. Artinya, bahwa memperjuangkan keadilan adalah hak semua manusia dan kezaliman dalam bentuk apa pun harus disingkirkan karena tidak sesuai dengan eksistensi penciptaan manusia itu sendiri.

Sebagai penganut Islam yang konsisten, pengarang berusaha merefleksikan realitas sosial dalam cerpennya. Konflik di Aceh menjadi peristiwa yang melukai tidak hanya rakyat Aceh, tetapi rakyat Indonesia pada umumnya yang mayoritas muslim. Sebagaimana kita tahu Operasi Jaring merah merupakan sandi operasi militer pada masa pemerintahan Orde Baru yang memaklumkan Aceh sebagai Daerah Operasi Militer (DOM) sekira tahun 1989-1998.

Di antara data yang diserahkan pegiat LSM kepada Komnas HAM antara lain, ada korban yang diculik, dianiaya, disetrum, dan kemudian ditembak di depan umum. Adapula yang diperkosa di depan anak atau di depan suaminya. Beberapa bagian bentuk kejahatan itu, ada kemiripan dengan modus opernadi penculikan aktivis prodemokrasi yang melibatkan Kopassus di Jakarta. Peristiwa pembantaian, penyiksaan, perkosaan yang dirasakan rakyat Aceh atas perbuatan militer selama DOM, sangat pedih dirasakan. Karena hal itu dilakukan oleh bangsa sendiri dan bukan bangsa lain yang pernah menjajah Indonesia seperti Belanda dan Jepang (Alchaidar, 1999: 111).

Beranjak dari peristiwa itulah pengarang menulis karya fiksi ini. Tujuannya tiada lain untuk menginformasikan dan menggugah kepedulian pembaca cerpennya tentang 
pelanggaran hak-hak asasi manusia di dunia pada umumnya dan di Indonesia pada khususnya. Mengapa ada kata menginformasikan? Bukankah informasi adalah bagian dari berita dan berarti menjadi tugas para jurnalis? Menurut Helvy, ia sering kecewa dengan berita di berbagai media (dunia) yang sering terdistorsi, terutama bila menyangkut dunia ketiga dan kaum muslimin. Konspirasi pembentukan opini publik melalui media dilakukan pihak-pihak tertentu demi keuntungan mereka (Rosa, 2003: viii).

Tokoh yang berkonfrontasi dengan tokoh protagonis, 'Inong' adalah tokoh kolektif karena terdiri dari puluhan orang dan digambarkan dalam cerpen ini dengan kata-kata: lelaki berseragam, tangan- tangan kekar, lelaki penyiksa. Mereka menembaki orang-orang, menebas leher Yunus Burong dan kepalanya dipertontonkan kepada penduduk desa, menelanjangi Rohani dan memperkosanya beramai-ramai sebelum rumah dan suaminya dibakar, serta mengikat dan menembaki Geuchik Harun. Kejadian yang luar biasa inilah yang hendak ditonjolkan pengarang, bahwa kebiadaban berdalih penjagaan keamanan hanya berdampak buruk pada rakyat sipil. Operasi Jaring Merah sebagai langkah pemerintah pada saat itu untuk menjaga keamanan hanya sebuah mitos, karena di lapangan telah terjadi perlakuan sewenang-wenang dan tidak manusiawi.

Helvy sendiri mengakui bahwa memang benar cerpen bukan fakta, tetapi cerpen saya selalu berangkat dari realita yang ada. Saya bereaksi, menanggapi peristiwa demi peristiwa dengan cerpen. Tak peduli peristiwa tentang apa di negeri mana, ketika itu menyentuh nurani saya, maka lahirlah sebuah karya. (Rosa, 2003:viii-ix).

Para jurnalis mewartakan fakta peristiwa seobjektif mungkin. Segala berita disiarkan melalui media cetak maupun elektronik. Termasuk tragedi kemanusiaan yang terjadi di Aceh. Namun dalam beberapa kejadian, dengan datangnya berbagai informasi maka wajarlah jika ada proses seleksi. Ada semacam prioritas, sehingga berita yang aktual tetap dikuti sedangkan yang lain ditanggalkan. Bukan karena berita-berita itu tidak penting, melainkan karena lama kelamaan berita itu menimbulkan bising bahkan asing. Helvy sebagai pengarang dengan cerpennya 
tampak tengah berusaha menguak residu memori kita dengan merevitalisasi peristiwa tersebut secara naratif dan tentunya fiktif. Cerpen Jaring-jaring Merah karya Helvy ini selain merupakan karya fiktif dan imajinatif, juga dipergunakan sebagai sarana untuk mengajak pembaca pada posisi berjaga-jaga tentang kemanusiawian kita melalui cerita yang tidak bernuansa bahagia, sarat bau anyir darah, lolongan kematian dan kelicikan.

\section{Ideologi tentang akhlak perempuan muslim}

Tokoh Inong merupakan gambaran ketidakberdayaan perempuan. Ia hanya bisa menelan kepahitan dan luka yang sulit untuk disembuhkan akibat perbuatan keji dari orang-orang yang telah merenggut keperawanannya. Bagi perempuan muslim, harga diri dan martabat yang tinggi adalah mempertahankan kegadisan. Ia hanya boleh ternoda oleh laki-laki yang dilegalkan dalam ikatan perkawinan. Selain itu, kehilangan keluarga dan calon suami yang dikasihinya bukan hal mudah untuk diterima. Tidak ada lagi keluarga tempatnya bercengkrama. Kondisi inilah yang membuatnya depresi atau terpukul, sehingga perilakunya dikategorikan sebagai gila oleh orang-orang di sekitarnya.

Sementara itu, tokoh perempuan lain, Cut Dini, merupakan representasi dari sosok pribadi muslimah yang diharapkan menjadi figur bagi perempuan muslim lainnya. Ia menggugurkan mitos bahwa perempuan muslim hanya bergulat di wilayah domestik seperti yang dituduhkan kaum feminis selama ini. Sosok Cut Dini tampil ke wilayah publik membela dan memperjuangkan hak kaum tertindas. Pada saat orang lain takpeduli dengan penderitaan korban, Inong, ia datang untuk merawat dan menjaganya. Dengan penuh kesabaran ia meneguhkan dan memulihkan kepercayaan dirinya.

Penggambaran sosok perempuan seperti Cut Dini ini sering dimunculkan dalam cerpen-cerpen lain karya Helvy Tiana Rosa seperti, sosok Cinta dalam cerpen Sebab Aku Angin Sebab Aku Cinta yang berjuang membela keyakinan agama dan mempertahankan tanah kelahirannya pada saat berlangsungnya 
penyerangan tempat-tempat ibadah dan perkampungan kaum muslimin di Ambon. Juga tokoh Gadis dalam cerpen Gadis Bening yang rela meninggalkan keluarganya di kota metropolitan- Jakarta, untuk menjadi sukarelawan di sebuah daerah muslim di Timor Timur sebelum memisahkan diri dari Republik Indonesia.

Selain itu, tokoh Rumaisha Dupont dalam cerpen Mon Ami Dibadirigma, seorang dokter muslimah berasal dari Perancis, yang diterjunkan ke Rwanda, daerah berlangsungnya konflik antar suku dan banyak lagi tokoh perempuan lain dalam cerpen-cerpennya yang bertema perjuangan kaum tertindas, baik yang berlatar cerita daerah konflik di Indonesia maupun di luar Indonesia, seperti Afghanistan, Moro, Myanmar, Liberia, Palestina, Azerbaijan, Alzajair, Kashmir, Chechnya, Bosnia Herzegofina, Kosovo, Somalia.

Penggambaran tokoh-tokoh seperti itu bisa jadi merupakan refleksi dari keyakinan pemahaman keagamaannya. Dengan cerpennya, tampak pengarang ingin mengklarifikasi isu-isu yang sering dipermasalahkan kaum feminis mengenai doktrin patriarkat dalam agama Islam, seperti penciptaan Adam Hawa, hukum waris, kesaksian, kualitas akal, dan syariat (ketentuan) agama antara laki-laki dan perempuan. Kesalahpahaman pandangan kaum feminis terhadap perempuan muslim didasarkan pada sebagian penafsiran agama yang kurang tepat terhadap sosok perempuan. Sosok perempuan dalam agama Islam memang sering ditafsirkan sebagai makhluk yang lebih rendah kedudukannya dibandingkan dengan laki-laki. Padahal, ayat-ayat lain yang memosisikan perempuan sebagai makhluk yang setara dengan laki-laki juga tidak sedikit.

\section{Ideologi tentang kewajiban beribadah sholat hanya diperuntukkan bagi manusia berakal sehat ('uquli salimah)}

Berbagai ideologi yang ditanamkan pengarang mengalir tanpa terasa namun kemunculannya tidak bisa dihindarkan. Pengarang tampaknya ingin konsisten terhadap apa yang diyakininya, yaitu 'mencerahkan' dirinya dan orang lain. Karya tulis fiksional yang dihasilkannya tetap berdasar kepada rambu-rambu syariat 
Islam. Ideologi yang berdasar pada syariat Islam itu dalam cerpen ini muncul sebagai penanda denotatif maupun konotatif, seperti dapat dilihat pada paragraf ini yang memunculkan ideologi tentang kewajiban beribadah sholat hanya diperuntukkan bagi manusia berakal sehat ("uquli salimah),

"Masya Allah, nanti perabotan itu rusak," suara Cut Dini, tetap lembut. "Benahi yang rapi lagi, ya. Aku mau shalat Lohor dulu," katanya.

"Mengapa aku tak pernah diajak shalat?" protesku. "Dulu aku shalat bersama keluargaku, sebelum aku bisa jadi burung," tukasku.

"Jangan menjadi burung, bila ingin salat seperti manusia," kata Cut Dini tersenyum.

Tokoh Inong pada paragraf di atas masih mengidentikan dirinya dengan burung. Kondisi kejiwaan tokoh ini memang terganggu setelah berbagai perlakuan yang kejam dan keji menimpanya sehingga ia lebih memilih menjadi burung, karena dengan demikian ia menjadi bebas dan melupakan kepahitan yang menimpanya. Kondisi tersebut dapat dikategorikan sebagai kondisi gila karena ia tidak sadar dengan apa yang telah dialaminya. Sementara itu, dalam agama Islam syarat syahnya seseorang untuk melaksanakan suatu peribadatan telah diatur sedemikian rupa, salah satunya yaitu berakal sehat, atau tidak gila dan harus dalam kondisi sadar. Terlebih pada pelaksaanaan sholat, Allah swt telah menyampaikan firmannya seperti dalam QS An Nisaa ayat 43, "Hai orang-orang yang beriman janganlah kamu sholat, sedang kamu dalam keadaan mabuk (tidak sadar) sehingga kamu mengerti apa yang kamu ucapkan”. Kalimat "Jangan menjadi burung, bila ingin salat seperti manusia," mengandung penanda denotatif dan konotatif. Kalimat tersebut dapat berarti bahwa burung bukanlah manusia, jadi tidak terkena kewajiban shalat atau makna lain hanya manusia normal yang bisa melaksanakan shalat

\section{Ideologi tentang sikap menerima ketetapan Allah}

Selain ideologi di atas, tampaknya pengarang masih menampilkan sosok Cut Dini sebagai perempuan muslim pilihan yang selalu hadir menemani Inong. Pada saat korban mengalami goncangan hebat, Cut Dinilah yang tidak kenal lelah 
mengingatkan korban untuk kembali kepada Allah, untuk memohon ampun kepada Allah (Istighfar). Penggunaan kalimat istigfar di bawah ini sekaligus menjadi simbol dari pesan dakwah yang hendak disampaikan pengarang.

“Ааaаaаaаaаaаaаaаaаaаaаaа!” aku berteriak sekuat-kuatnya.

"Astaghfirullah, Inong! Inong, bangun!" dua tangan menggoncang-goncang badanku. Airmataku menganak sungai, tetapi aku tak bisa bangun, sebab aku berada di dalam jaring! Banyak orang-orang sepertiku di sini, di dalam jaringjaring merah ini.

"Inong, istighfar..." (halaman 8)

Paragraf di atas juga mengandung ideologi bahwa kondisi kejiwaan korban yang sakit, terpukul karena penderitaan yang begitu besar adalah sebuah kenyataan yang tidak bisa dielakkan. Bagaimanapun, sebagai manusia ciptaan Allah, kejadian luar biasa yang menimpa Inong juga korban-korban lain tidak luput dari sebuah ketetapan, yaitu ketetapan Allah sebagai Sang Khalik. Jika hal ini disikapi sebagai sebuah ketetapan dari yang memiliki hidup, tiada jalan lain terapinya adalah memohon kekuatan kepada Yang Maha Menetapkan tersebut. Kalimat istighfar di sini tampaknya untuk mengingatkan posisi kita hanya sebagai makhluk yang hidup dan kehidupannya sebenarnya sudah ada dalam skenario pembuat kehidupan, yaitu Allah SWT.

\section{Ideologi Persaudaraan Islam (Ukhuwah Islamiyah)}

Paragraf di bawah ini menggambarkan bagaimana Cut Dini meyakinkan korban bahwa Sang Maha Pencipta selalu dekat dan melihat apa yang terjadi pada hamba-Nya. Sikap tegar yang lahir dari pengakuan bahwa kemampuan dan kekuatan yang dimiliki seorang hamba adalah semata kemampuan dan kekuatan yang diberikan-Nya, merupakan jawaban untuk menghadapi segala ujian-Nya. Kalimat Laa haula walaa qumwata illa billah....” yang artinya tiada daya kemampuan menolak pengaruh buruk setan dan dan kekuatan melaksanakan perintah Allah melainkan karena kemampuan dan kekuatan yang diberikan oleh Allah semata.

Di tanah kebanggaanku hanya tersisa nestapa!! 
Tak ada yang mendengar. Sebuah pelukan yang sangat erat kurasakan. Lalu airmata seseorang yang menetes-netes dan bercampur dengan aliran air di pipiku.

"Allab tak akan membiarkan mereka, Inong! Tak akan! Kau harus sembuh, Inong! Semua sudah berlalu. Peristiwa empat tahun lalu dan rezim ini. Tegar, Inong! Tegar! Laa haula walaa quwwata illa billah...."

Kabur. Samar kulihat Cut Dini. Wajah tulus dengan kerudung putih itu. Ia mengusap airmataku (halaman 9)

Dalam skenario pengarang, ketulusan Cut Dini berbagi kasih yang dimunculkan dengan sikap mencurahkan perhatiannya terhadap Inong juga sebuah ideologi lain, yaitu ideologi ukhuwah islamiyah (persaudaraan umat Islam). Cut Dini bukanlah karib atau kerabat Inong. Keberadaannya di sana adalah sebuah panggilan sebagai seorang perempuan mukmin dalam bentuk kepedulian terhadap sesama ummat Islam. sebagaimana telah difirmankan oleh Allah swt dalam QS Al Hujurat (49) : 10 bahwa Sesungguhnya orang-orang mukmin adalab bersaudara ... Selanjutnya spirit Islam yang tidak mengenal jenis kelamin, suku bangsa/ etnis, ras, dalam penghambaan kepada Allah dapat dilihat dalam firman-Nya QS Al Hujurat (49) : 13,

Hai manusia, sesungguhnya Kami telah menciptakan kamu dari seorang laki-laki dan seorang perempuan dan menjadikan kamu berbangsa bangsa dan bersuku-suku supaya kamu saling mengenal. Sesunggubnya orang yang paling mulia di antara kamu di sisi Allab ialah orang yang paling bertakwa di antara kamu. Sesunggubnya Allab Maba Mengetahui lagi Maba Mengenal.

\section{Analisis Sintagmatik.}

Saat unit yang dipilih dari sebuah paradigma dikombinasikan dengan unit lainnya, kombinasi tersebut disebut sintagma. Aspek penting dari analis sintagmatik adalah aturan atau konvensi yang menjadi dasar pembuatan dari kombinasi unit-unit tersebut. Tokoh Inong masih digambarkan dengan stereotip perempuan, berkarakter emosional, lemah, dan tidak berdaya. Kondisi takberdayaa ini dimunculkan pengarang untuk mendukung judul cerpen ini, yaitu Jaring-jaring Merah. Menurut Helvy, kisah ini sesungguhnya terinspirasi dari Operasi Jaring Merah (OJM) TNI di Aceh pada masa Orde Baru selama kurun waktu sembilan tahun (1989-1998). Dengan adanya OJM ini, ia membayangkan rakyat Aceh berada atau terperangkap dalam jaring. Tokoh utama dibuat 
gila untuk mendukung kelogisan cerita karena hanya orang gila saja yang merasa dirinya dalam jaring.

Pesan utama dapat kita tangkap di sini bahwa dalam kondisi gila pun tokoh utama, Inong, masih dapat mengadakan perlawan. Ia melawan dengan kegilaannya. Di pengadilan mungkin kesaksiannya tidak dapat diterima, tetapi dapat dibayangkan dalam kegilaannya dia bisa membuat anggota TNI/ Kopasus berlarian. Bagaimana ia menceracau dan melempari para penindasnya sebagai bentuk perlawanan, dapat dilihat pada kalimat berikut ini,

Apa ? Gadis gila?? Kukepakkan sayapku dan menukik ke arah dua lelaki itu. Kulempar mereka dengan apa pun yang kutemui di meja dan lantai. Aku berlari ke dapur, dan kembali menimpuki mereka dengan panci dan penggorengan. Mereka berteriak-teriak seperti anak kecil dan berebutan keluar rumah. Pasti itu ayah yang memperkosaku! Pasti ia teman para pembunuh itu! Pasti mereka orang-orang gila yang suka menakut-nakuti orang! Paling tidak mereka cuak! Aku benci cuak! (halaman 6)

"Pergiii! Pergiii semuaaa!" teriakku. "Pergiiiiil" aku menjerit sekuat-kuatnya. "Pergiiiiil" Aku menceracau. Sekujur badanku terasa bergetar, terasa berputar. Orang-orang ini tersentak, menatapku kasihan. Hah, apa peduliku?! Aku ingin berteriak, mengamuk, memorakporandakan apa dan siapa pun yang ada di hadapanku! Aku.... (halaman 9)

Pengarang hendak menyampaikan pesan bahwa keberadaan Inong menjadi bentuk perlawanan bagi perempuan muslim lainnya. Artinya kisah ini dapat menjadi ibrah (pelajaran) sehingga para perempuan muslim bisa melawan dan membela keadilan jika hakhaknya dilanggar. Sebagai sebuah teks fiksional, kisah ini sangat mungkin mengandung ambiguitas. Tokoh yang gila bisa saja bukan hanya Inong, karena orang gila mana yang masih bisa mengingat begitu detail kisah tragis yang menimpanya. Hal ini dapat kita telaah dari alur cerita; bagaimana dari awal hingga akhir cerpen, kisah dituturkan oleh 'aku' atau sudut pandang tokoh utama, Inong. Dia hanya menjadi korban dari kesewenangwenangan, dan dia menyuarakan kebenaran. Pengarang memunculkan keadaan ini dalam kalimat,

“Aku "Aku ingin memakainya," lirihku. "Apa aku gila?" tanyaku. Cut Dini menatap bola mataku dalam. "Menurutmu?". Aku menggeleng kuat-kuat. Menggaruk-garuk kepala. "Kau sakit. Kau sangat terpukul," ujar Cut Dini. Kulihat ia menggigit bibirnya sesaat. Lalu dengan cekatan membungkus baju itu dengan 
koran Aku mengangguk-angguk. Terus mengangguk-angguk, sambil menggoyanggoyangkan kedua kakiku. Aku suka membantah orang, tetapi tidak Cut Dini. (halaman 5)

Pada perspektif lain, dapat saja yang "gila" di sini adalah oknum anggota Kopasus. Gila dalam hal apa dapat kita baca dari perbuatan-perbuatan mereka memperkosa, menyiksa membantai warga sipil Aceh yang tidak bersalah. Dalam cerpen, tentu saja label gila ini diungkapakan oleh tokoh utama- Inong, dalam kalimat-kalimat seperti ini;

Aku pura-pura tidak mendengar perkataan si loreng-loreng itu. Mereka gila karena mengira aku gila. (halaman 3)

Pasti itu ayah yang memperkosaku! Pasti ia teman para pembunuh itu! Pasti mereka orang-orang gila yang suka menakut-nakuti orang! (halaman 6)

Data dan fakta telah menunjukkan bagaimana rakyat Aceh diperlakukan tidak adil. Jadi menurut Helvy, pesan yang hendak disampaikan bukan menyulut antipati pada hegemoni kekuasaaan, tetapi menegakkan keadilan. Pada saat kesewenang-wenangan merajai, tidak ada kata lain selain melawannya dengan kemampuan optimal yang dimilki. Sekalipun hal itu dilakukan oleh seorang perempuan dengan kondisi psikis tidak normal.

Tokoh Cut Dini, mitos yang diciptakan pengarang, ditempatkan pada posisi perempuan muslim sebenarnya. Perempuan yang memperjuangkan hak perempuan. Perempuan yang memiliki kepedulian sosial yang tinggi. Pada saat perempuan lainnya sibuk memikirkan keindahan tubuh dan aksesoris yang pantas dipakainya, serta karier pribadi dan berbagai cara yang ditempuh untuk memperoleh kesenangan hidup sekalipun dengan cara tidak halal, tokoh ini maju untuk membantu korban-korban kebiadaban akibat OJM. Dia berusaha menjadi perempuan yang merdeka dengan keyakinan yang dimilikinya. Berdasarkan keyakinan yang bersumber pada wahyu Ilahi, perempuan adalah makhluk yang setara dengan laki-laki. Di samping itu, sebuah hadits menungkapkan bahwa perempuan adalah saudara kandung laki-laki (HR Abu Dawud dan Nasai). Kata saudara kandung di sini menunjukkan adanya pertalian yang dekat dan fitri antara kedua jenis manusia, laki-laki dan perempuan. 
Tokoh ini bukan hanya simbol perempuan muslim ideal sesuai dengan $\mathrm{Al}$ quran, tetapi sekaligus menepis mitos bahwa perempuan adalah makhluk subordinat juga menepis mitos bahwa perempuan muslim hanya berkutat di sektor domestik sebagaimana sering dituduhkan kaum feminis sosialis dan liberalis. Kesalahan Barat dalam memandang perempuan muslim adalah karena ketidakpahamannya terhadap sejarah, bagaimana peran perempuan pada masa Rasulullah, Muhammad saw dan para sahabat Khulafa-ur Rasyidin. Tidak sedikit perempuan-perempuan muslim ini yang berjuang ke medan laga, membantu tentara sesuai dengan keterampilannya. Hal ini dicontohkan oleh istri rasulullah Muhammad saw, Aisyah binti Abu Bakr.

Tanda indeksikal yang menunjukan tokoh ini sebagai perempuan muslim adalah penggunaan kheroudung (jilbab). Pengarang menuturkan pandangan mengapa setiap tokoh perempuan muslim dalam cerpennya ditandai dengan penggunaan jilbab, yaitu karena hal itu termasuk bagian dari syiar / dakwah Islam yang selama ini dilakukannya. Bagi Helvy, penggunaan jilbab pada tokoh-tokoh cerpennya bukan hanya tempelan atau simbol belaka tetapi membuat salah satu bentuk perilaku yang akhirnya mempengaruhi bentuk perilaku secara keseluruhan dari tokohnya. Dengan menggunakan jilbab, tokoh tersebut memiliki konsep tentang perempuan muslim, konsep tentang dirinya. Bagaimana tokoh Cinta dalam Sebab Aku Cinta Sebab Aku Angin, perempuan muslim palestina dalam Ketika Batu Bicara, dan kisah-kisah lainnya. Salah satu alasan pengarang mengenai tokoh utama muslim yang mengenakan jilbab sebagai identitas utama bagi muslimah adalah karena perintah Allah di dalam Al Quran, surat Al Ahzab; 59. (Isi dari firman Allah swt tersebut adalah sebagai berikut,

Hai Nabi, katakanlah kepada istri-istrimu, anak-anak perempuanmu, dan istri-istri orang mukmin, bendaklab mereka mengulurkan jilbabnya ke selurub tubub mereka. Yang demikian itu supaya mereka lebih dikenal, karena itu mereka tidak diganggu. Dan Allab adalah Maha Pengampun lagi Maha Penyayang (QS Al Abzab 59)

Selain penggambaran perempuan dengan dua kondisi, kisah ini sarat juga dengan penggambaran tema perjuangan, dikotomi antara kaum tertindas dan penindas. Tentu saja penindas digambarkan memiliki karakter angkuh, sewenang-wenang, kejam, keji, biadab, tidak berpreikemanusiaan, dan sebagainya. Sifat-sifat ini merupakan karakter yang 
berkonotasi negatif dalam masyarakat Indonesia. Penindas yang digambarkan sebagai orang-orang berseragam, barambut cepak, bersepatu lars, berbadan tegap, tentu menunjuk kepada militer yang menjalankan misi OJM di Aceh pada saat itu.

\section{Kesimpulan}

Dari hasil analisis semiotika terhadap cerpen karya Helvy Tiana Rosa dengan judul Jaring-jaring Merah ini dapat ditarik simpulan bahwa teks fiksional ini dipenuhi oleh tanda-tanda semiotika. Kemunculannya pada kata, frasa, kalimat, hingga alinea begitu intens, menstimulasi imajinasi pembaca sehingga nurani terusik dan emosi terbangun. Dunia rekaan yang dikonstruksikan pengarang tidak terasa, karena latar cerita (setting) di sebuah daerah, yaitu Aceh yang memang secara faktual pernah mengalami peristiwa menyedihkan saat diberlakuan sebagai Daerah Operasi Militer (DOM) tahun 1989 sampai dengan 1998. Hal itulah yang membedakan komunikasi puitik dengan komunikasi lainnya. Informasi yang didapat dari pemberitaan di media massa elektronik maupun cetak sebatas memenuhi dimensi kognitif dan tidak cukup membangkitkan dimensi afektif apalagi psikomotorik. Pesan dakwah Islam yang dikemas dalam cerpen ini tampaknya menyajikan sisi lain kemanusiaan kita, karena menyajikan kekerasan fisik maupun verbal. Hal ini barangkali untuk membedakannya dengan misi dan visi Islam sesungguhnya dan memotret realitas yang dihadapi ummat Islam itu sendiri; bahwa hidup tak selamanya harmonis dan indah, bahwa hidup bagi sebagian orang dilalui dengan penuh perjuangan.

Ideologi yang ditanamkan pengarang dalam cerpen ini pertama, ideologi tentang keadilan dan kemerdekaan serta hak azasi manusia. Ideologi ini mengungkapkan bahwa penjajahan bisa saja dilakukan oleh pemerintah dalam hal ini aparat TNI, sehingga memunculkan anggapan bahwa peran TNI sebagai penjaga keamanan merupakan mitos belaka. Kedua, ideologi tentang akhlak perempuan muslim dan penjelasan posisi perempuan dalam Islam. Ideologi ini sekaligus menggugurkan mitos bahwa perempuan muslim hanya berkutat di ranah domestik dan tidak peduli terhadap tanggung jawab sosial. Ketiga, ideologi tentang kewajiban beribadah sholat hanya diperuntukkan bagi manusia 
berakal sehat ('uquli salimah). Keempat, ideologi tentang sikap menerima ketetapan Allah dan kelima Ideologi persaudaraan umat Islam (ukhuwah islamiyah).

\section{Referensi}

\section{Buku}

Alchaidar, dkk. (1999) Aceh Bersimbah Darah: Mengungkap Penerapan Status Daerah Operasi Militer (DOM) di Aceh 1989-1998. Cetakan Kelima. Jakarta: Pustaka AlKautsar

Barthes, Roland. (2006). Mitologi. Nurhadi (Terj.). Yogyakarta: Kreasi Wacana.

Eriyanto. (2011). Analisis Wacana, Pengantar Analisis Teks Media. Yogyakarta: LKiS

Littlejohn, Stephen W dan Karen A Foss. (2009). Teori komunikasi-Theories of Human Communication. Jakarta: Salemba Humanika

Luxemburg, Jan van dkk. (1992). Pengantar Ilmu Sastra. Diindonesiakan Oleh Dick Hartoko. Jakarta:PT Gramedia .

Mulyana, Deddy. (2005). Nuansa-nuansa Komunikasi. Bandung: Remaja Rosdakarya.

Mulyana, Deddy. (2005). Bidadari Kerudung Biru: Kumpulan Cerita Deddy Mulyana. Bandung: Media Percikan Iman.

Mulyana, Deddy. (2007). Ilmu Komunikasi Suatu Pengantar. Bandung: Remaja Rosdakarya.

Mulyana, Deddy. (2010). Metodologi Penelitian Kualitatif. cetakan VII . Bandung: Remaja Rosdakarya.

Nurgiantoro, Burhan. (2000). Teori Pengkajian Fiksi. Yogyakarta: Gadjah Mada University Press.

Ratna, Nyoman Kutha. (2012). Teori,Metode, dan Teknik Penelitian Sastra. Cetakan X Yogyakarta: Pustaka Pelajar.

Rosa, Helvy Tiana. (2003). Segenggam Gumam, Esai-esai tentang Sastra dan Kepenulisan. Bandung: Syaamil Cipta Media .

Rosa, Helvy Tiana. (2004). Ketika Mas Gagah Pergi. Kumpulan Cerpen Pilihan. Bandung: Syaamil Cipta Media 
Rosa, Helvy Tiana. (2014). Juragan Haji. Kumpulan cerpen pilihan dwi Bahasa. Bandung: Gramedia Pustaka utama.

Sobur, Alex. (.2009). Semiotika Komunikasi. Bandung: Remaja Rosdakarya

Sobur, Alex. (2012). Analisis Teks Media. Bandung: Remaja Rosdakarya.

Yayasan Penyelengara Penterjemah Alquran \& Lajnah Pentashih Alquran. (2010). Al Aly Al quran dan Terjemahannya. Bandung: CV Penerbit Diponegoro

Zoest, Aart Van. (1993). Semiotika: Tentang Tanda, Cara Kerjanya dan Apa yang Kita Lakukan Dengannya. Diindonesiakan oleh Ani Sukowati. Jakarta: Yayasan Sumber Agung.

\section{Jurnal}

Widiningtyas, Theresia. (2002) Representasi Keluarga dalam Sinetron. Jurnal Thesis No I/Volume I/2002. Jakarta:Universitas Indonesia. 